\title{
Composition, yield, and functionality of reduced-fat Oaxaca cheese: Effects of using skim milk or a dry milk protein concentrate
}

\author{
I. Caro, ${ }^{*}$ S. Soto, † M. J. Franco,† M. Meza-Nieto,† R. H. Alfaro-Rodríguez,† and J. Mateo*1 \\ *Departamento de Higiene y Tecnología de los Alimentos, Universidad de León, 24071 Spain \\ †Centro de Investigaciones en Ciencia y Tecnología de los Alimentos, Instituto de Ciencias Agropecuarias, \\ Universidad Autónoma del Estado de Hidalgo, 43000 Mexico
}

\begin{abstract}
The effect of adding either skim milk or a commercial dry milk protein concentrate (MPC) to whole milk on the composition, yield, and functional properties of Mexican Oaxaca cheese were investigated. Five batches of Oaxaca cheeses were produced. One batch (the control) was produced from whole milk containing $3.5 \%$ fat and $9 \%$ nonfat solids (SNF). Two batches were produced from milk standardized with skim milk to 2.7 and $1.8 \%$ fat, maintaining the SNF content at $9 \%$. In the other 2 batches, an MPC (40\% protein content) was used to standardize the milk to a SNF content of 10 and $11 \%$, maintaining the milk fat content at $3.5 \%$. The use of either skim milk or MPC caused a significant decrease in the fat percentage in cheese. The use of skim milk or MPC showed a nonsignificant tendency to lower total solids and fat recoveries in cheese. Actual, dry matter, and moisture-adjusted cheese yields significantly decreased with skim milk addition, but increased with MPC addition. However, normalized yields adjusted to milk fat and protein reference levels did not show significant differences between treatments. Considering skim milk-added and control cheeses, actual yield increased with cheese milk fat content at a rate of 1.34 $\mathrm{kg} / \mathrm{kg}$ of fat $(\mathrm{R}=0.88)$. In addition, cheese milk fat and SNF:fat ratio proved to be strong individual predictors of cheese moisture-adjusted yield $\left(\mathrm{r}^{2} \approx 0.90\right)$. Taking into account the results obtained from control and MPC-added cheeses, a 2.0-kg cheese yield increase rate per $\mathrm{kg}$ of milk MPC protein was observed $(\mathrm{R}=$ 0.89), with TS and SNF being the strongest predictors for moisture adjusted yield $\left(\mathrm{r}^{2} \approx 0.77\right)$. Reduced-fat Oaxaca cheese functionality differed from that of controls. In unmelted reduced-fat cheeses, hardness and springiness increased. In melted reduced-fat cheeses, meltability and free oil increased, but stretchability decreased. These changes were related to differences
\end{abstract}

Received January 22, 2010.

Accepted November 8, 2010.

${ }^{1}$ Corresponding author: jmato@unileon.es in cheese composition, mainly fat in dry matter and calcium in SNF.

Key words: cheese yield, functional property, pasta filata, reduced-fat cheese

\section{INTRODUCTION}

Oaxaca cheese is one of the most popular Mexican cheeses; it is widely used in Mexican dishes, usually melted. It is a pasta filata cheese normally produced from raw milk when manufactured at small dairy plants. The Oaxaca cheese-making process involves curd acidification (until a $\mathrm{pH}$ of approximately 5.3 is reached), kneading (in hot water), and stretching. Long, thin strips of curd are formed, which are cooled in chilled water, salted, and cut into segments. The segments are then wound into balls. Only one study has been found in the literature on the chemical composition of Oaxaca cheese, and it is related to the use of fermented cheese whey for its manufacture (Aguilar-Uscanga et al., 2006).

Over the last few decades, because of dietary guidelines and the growing desire for reduced-fat products, the market for reduced-fat cheeses has increased (Childs and Drake, 2009). However, cheeses with reduced fat levels have been found to be associated with deleterious effects on cheese functionality (i.e., resulting in excessively firm and elastic, harder, less meltable cheeses; Rodríguez, 1998; Mistry, 2001).

Reduced-fat cheeses can be produced with part-skim milk, although skimming usually results in a lower cheese yield (Van Vliet, 1991; Shakeel-Ur-Rehman et al., 2003). Furthermore, the addition of casein in the form of milk protein concentrate (MPC) is another modern day technology used for the manufacture of these cheeses. The use of MPC results in a higher cheese yield, thus, improving the competitiveness of commodity-type cheese production (Shakeel-Ur-Rehman et al., 2003; Guinee et al., 2006). Milk protein concentrate is spray-dried ultrafiltration retentate obtained from skim milk, with protein contents between 40 and $85 \%$. In MPC, whey proteins and caseins are present in the 
same proportion as in milk (Kameswaran and Smith, 1999). According to these authors, MPC has rennet coagulation properties similar to those of milk.

The aim of the present study is to investigate the effects of lowering the cheese milk fat content by adding skim milk or MPC to whole milk on composition, yield, and functional properties of Oaxaca cheese.

\section{MATERIALS AND METHODS}

\section{Cheese Manufacture and Sampling Procedures}

Five Oaxaca cheese batches were produced in triplicate (a $5 \times 3$ randomized complete block design) on 15 consecutive working days, using milk $(50 \mathrm{~kg})$ that was obtained the previous day at the Rancho Universitario, Universidad Autónoma del Estado de Hidalgo (Mexico), with mean fat and SNF contents of 3.5 and $9.0 \%$, respectively. One batch was produced with whole milk without any modifications (control batch). For 2 batches, milk was previously standardized to fat percentages of $2.7\left(\mathbf{S M}_{3 / 4 \text {-fat }}\right)$ and $1.8\left(\mathbf{S M}_{\text {Half-fat }}\right)$ by adding skim milk. When needed, the SNF content of the skim milk was adjusted to $9.0 \%$ by adding water. For the other 2 batches, 1.5 and $3.0 \mathrm{~kg}$ of MPC/100 kg of milk $\left(\mathbf{M P C}_{1.5}\right.$ and $\mathbf{M} \mathbf{P C}_{3.0}$ batches, respectively) were added to achieve cheese milk with approximately 10.0 and $11.0 \% \mathrm{SNF}$, respectively (fat content was $3.5 \%$ for both batches). The MPC was obtained from NZMP S.A of C.V (Mexico City, Mexico), and contained (per $100 \mathrm{~g}$ of MPC) $40 \mathrm{~g}$ of protein, $4 \mathrm{~g}$ of moisture, $45 \mathrm{~g}$ of lactose, $1.2 \mathrm{~g}$ of fat, and $9 \mathrm{~g}$ of ash. The calculated amount of MPC powder was dispersed in $2 \mathrm{~L}$ of milk previously heated to $50^{\circ} \mathrm{C}$ with an automatic blender at high speed and was manually agitated for 30 min just before adding to milk.

The cheese-making process started with cheese milk pasteurization $\left(63^{\circ} \mathrm{C}\right.$ for $\left.30 \mathrm{~min}\right)$. After cooling to $35^{\circ} \mathrm{C}$, cheese milk was placed in an open vat, and $\mathrm{CaCl}_{2}(20 \mathrm{~g} / 100 \mathrm{~kg}$ of milk) and a mixture (weight ratio 7:3) of mesophilic and thermophilic commercial lyophilized starter cultures (Lyofast CMS and Lyofast Y, respectively; Sacco, Cadorago, Italy; $1 \mathrm{~g}$ of starter mixture/100 kg of cheese milk), previously dispersed in a small amount of pasteurized cheese milk, was added. Then, the cultured milk was incubated in the vat $\left(35^{\circ} \mathrm{C}\right)$, with gentle agitation $(2$ min every $20 \mathrm{~min})$, for the time necessary for the acidity to increase from 0.015 to $0.020 \%$ lactic acid. Afterward, microbial liquid rennet (Mucor miehei, 1:20,000 strength; Chemostar double-strength chymosin; Rhodia Inc., Madison, WI) was added $(15 \mathrm{~mL} / 100 \mathrm{~kg})$, the milk was allowed to set at $35^{\circ} \mathrm{C}$ for 30 to $45 \mathrm{~min}$, and then the curd was cut for 3 min into $1-\mathrm{cm}^{3}$ cubes, which were gently stirred in the whey for 15 min. Afterward, the curd-whey mixture was gradually heated to $38^{\circ} \mathrm{C}$ (over a 10 -min period) while continually stirred, and then was maintained at this temperature for $30 \mathrm{~min}$, with stirring for $5 \mathrm{~min}$ every $8 \mathrm{~min}$. The whey was then partially drained (approximately $75 \%$ of total volume), and the curd grains were racked to a side of the vat and allowed to set for $15 \mathrm{~min}$. The curd was then cut into 5 rectangular blocks (each weighting approximately $1 \mathrm{~kg}$ ), which were left in the vat at $38^{\circ} \mathrm{C}$ (turning every $20 \mathrm{~min}$ ) until the curd $\mathrm{pH}$ reached a value of between 5.2 and 5.4. The remaining whey was then drained and the blocks of curd were transferred to another open vat, hand broken into small pieces, and kneaded in $15 \mathrm{~L}$ of hot water at $75^{\circ} \mathrm{C}$, for 10 to $15 \mathrm{~min}$, until an elastic and smooth curd was obtained. The curd was then manually stretched and 2 strips were obtained: a short strip (approximately $20 \mathrm{~cm}$ long and $5 \mathrm{~cm}$ in diameter), which was used for texture measurement, and a long strip (a few meters long and approximately $2 \mathrm{~cm}$ in diameter), which was used for the rest of the analysis. Both strips were cooled in chilled water for $10 \mathrm{~min}$, and then removed from the water. Cheese strips were laid out as a single layer on a stainless-steel surface. The strips were left to drain for 10 min and then sprinkled with $\mathrm{NaCl}(2.0 \mathrm{~g} / 100 \mathrm{~g})$ and covered with a plastic film to prevent excessive drying, at which point, they were left for $16 \mathrm{~h}$ at $10^{\circ} \mathrm{C}$. The longer strip was then immediately cut into segments of approximately $0.5 \mathrm{~kg}$ each, which were wound into a ball shape. All of the balls and the wider strap were weighed, and the values obtained were further used for yield calculations.

All cheeses were stored under vacuum packaging for $3 \mathrm{~d}$ at $5^{\circ} \mathrm{C}$ to simulate the conditions at the retail market stores. Then, $\mathrm{pH}$ and functional analysis were performed, and a sample of $250 \mathrm{~g}$ of cheese from each manufacturing day was taken for analysis. Samples were blended with a food processor and kept frozen at $-18^{\circ} \mathrm{C}$ until further physicochemical and sensory analysis.

\section{Physicochemical Analysis of Cheese Milk and Cheeses}

Infrared spectroscopy with a MilkoScan 5000 (Foss Electric A/S, Hillerød, Denmark) was used for milk fat, protein, lactose, and TS analyses. Milk pH was measured using a $\mathrm{pH}$ meter after the sample was homogenized with distilled water (1:5, wt/vol); milk acidity was titrated with $0.10 \mathrm{M} \mathrm{NaOH}$ using phenolphthalein as the indicator; and specific gravity was determined at $20^{\circ} \mathrm{C}$ using a manual hydrometer. Furthermore, cheeses were analyzed for moisture, fat, protein, and ash contents following AOAC methods 926.08, 933.05, 920.123, and 935.42, respectively (AOAC, 1999). Water activity 
was determined using a CX-2 hygrometer (Decagon Device Inc., Pullman, WA) at $25^{\circ} \mathrm{C}$. All these measurements were performed in triplicate.

Lactic and acetic acids were analyzed following the method described by González de Llano et al. (1996). Sugars and $\mathrm{NaCl}$ were analyzed using the same methodology, except that the column temperature was $60^{\circ} \mathrm{C}$, detection was performed using a differential refractometer, and the eluent was $5 \mathrm{mM} \mathrm{H}_{2} \mathrm{SO}_{4}$ at a constant flow of $0.6 \mathrm{~mL} / \mathrm{min}$. Finally, calcium and phosphorous concentrations were analyzed by inductively coupled plasma-atomic emission spectroscopy (Osorio et al., 2007). All these analysis were carried out in duplicate.

\section{Measuring Recoveries and Cheese Yields}

Fat, TS, and SNF recovered from the Oaxaca cheeses (expressed as percentage) were calculated from the levels of these components in cheese milk and cheese (Guinee et al., 2006). Actual cheese and cheese DM yields were determined as the amount $(\mathrm{kg})$ of cheese and cheese TS, respectively, obtained per $100 \mathrm{~kg}$ of cheese milk. The actual yield normalized to reference levels of cheese milk fat $(3.5 \mathrm{~g} / 100 \mathrm{~g})$ and protein $(3.3 \mathrm{~g} / 100 \mathrm{~g})$ also was calculated. Moreover, yield was expressed as moisture-adjusted yield, calculated using the moisture content of $50.8 \mathrm{~g} / 100 \mathrm{~g}$ (the mean value obtained from 10 samples of commercial Oaxaca cheeses; I. Caro, unpublished data), and as normalized moisture-adjusted yield, for cheese milk adjusted to reference levels of fat and protein $(3.5$ and $3.3 \mathrm{~kg} / 100 \mathrm{~kg}$, respectively). The equations used for calculating all these forms of expressing cheese yield are those of Guinee et al. (2006).

\section{Cheese Functionality}

Instrumental texture profile analysis was performed with a texture analyzer TA.XT2i (Stable Micro Systems, Godalming, UK) fitted with a $50-\mathrm{kg}$ load cell. Four cubes of unmelted cheese $\left(2 \mathrm{~cm}^{3}\right)$ were obtained from each sample and kept in an airtight plastic bag overnight at $8^{\circ} \mathrm{C}$. Samples were removed and immediately compressed twice, at room temperature, with a 5 -cm-diameter cylindrical probe at $1 \mathrm{~mm} / \mathrm{s}$ to half the original height. The characteristics determined from the force-time curves, namely hardness, adhesiveness, springiness, and cohesiveness, were those described by Van Vliet (1991).

Meltability was determined in triplicate following the method described by Richoux et al. (2001), which was derived from the Schreiber test, and expressed as the percentage increase in the cheese disc diameter upon heating at $225^{\circ} \mathrm{C}$ for $3 \mathrm{~min}$. Furthermore, free oil in melted cheese was determined in duplicate following the procedure described by Kindstedt and Fox (1991).
Finally, the changes in meltability over a period of time were measured by repeated observations during the heating of cheeses at different temperatures following the cooking (baking) test described by Wang and Sun (2002) with modifications in sample preparation, heating temperature interval, and image capture system. The method used was as follows: In duplicate, 200 $\mathrm{g}$ of each cheese sample was blended in a food processor and 15-g amounts were molded into a set of 4 disks (4.5 $\mathrm{mm}$ diameter $\times 6 \mathrm{~mm}$ height). Cheese cylinders, thus formed, were placed onto wheat-flour tortillas and heated in an oven at 1 of 4 different temperatures (125, 150,175 , and $200^{\circ} \mathrm{C}$ ) for up to $20 \mathrm{~min}$. During baking the oven pan was removed at $1,2,3,4,5,6,8,10$, $12,14,16,18$, and $20 \mathrm{~min}$ to capture a digital image of melting cheese samples and then placed again into the oven. Meltability was expressed as the percentage increase in diameter of the cheese discs on heating. Additionally, color was measured on the surface of the cheese samples both unmelted and after the 20-min heating followed by a 15-min cooling period at room temperature, with a CM-508d (Minolta, Osaka, Japan) chromameter (illuminant: D65; visual angle: $10^{\circ}$ ).

A sensory analysis of free oil and stretchability in melted Oaxaca cheese was performed by 8 trained panelists following ISO $(1993,2008)$ standards 8586 and 8589 , and based on the procedures described by the USDA (1980) and Govindasamy-Lucey et al. (2007), respectively. The members of the panel received 15 1-h training sessions to perform the analysis. Samples (30 $\mathrm{g}$ of cheese) were placed on the center of a corn tortilla (unrolled) and heated in a $1,650-\mathrm{W}$ microwave oven for $30 \mathrm{~s}$ before evaluation. For free oil, a 1-to-9 point scale was used $(1=$ free oil was not observed; $9=$ the entire surface was covered in free oil). For stretchability, panelists were asked to dip the tines of a 4-tine stainless-steel fork into the mass of melted cheese to a depth of 3 $\mathrm{mm}$ at a $45^{\circ}$ angle before lifting the fork vertically and slowly. The vertical elongation at break was then estimated with the help of a metric measuring tape, and a 9 -point structured scale was used for the evaluation (1 for $0.1 \mathrm{~m}$, and 9 for $0.9 \mathrm{~m}$ elongation at break).

\section{Statistical Analysis}

Statistical analysis was performed with the software package Statistica for Windows (release 6.0, Statsoft Inc., Tulsa, OK). One-way ANOVA analysis was carried out and means of variables for each batch were compared by using the post-hoc Newman-Keuls test. Yield predictive formulas were estimated using linear regression analysis, which also was performed to study the correlations between cheese compositional and functional characteristics. 
Table 1. Chemical composition (mean values and standard deviations) of cheese milk standardized with skim milk or milk protein concentrate (MPC)

\begin{tabular}{lccccr}
\hline & \multicolumn{5}{c}{ Treatment $^{1}$} \\
\cline { 2 - 6 } $\begin{array}{l}\text { Item } \\
(\mathrm{g} / 100 \mathrm{~g})\end{array}$ & $\begin{array}{c}\text { Control } \\
(\mathrm{n}=3)\end{array}$ & $\begin{array}{c}\mathrm{SM}_{\text {Half-fat }} \\
(\mathrm{n}=3)\end{array}$ & $\begin{array}{c}\mathrm{SM}_{3 / 4 \text {-fat }} \\
(\mathrm{n}=3)\end{array}$ & $\begin{array}{c}\mathrm{MPC}_{1.5} \\
(\mathrm{n}=3)\end{array}$ & $\begin{array}{c}\mathrm{MPC}_{3.0} \\
(\mathrm{n}=3)\end{array}$ \\
\hline Lactic acid & $0.154 \pm 0.002^{\mathrm{b}}$ & $0.152 \pm 0.002^{\mathrm{b}}$ & $0.142 \pm 0.006^{\mathrm{b}}$ & $0.178 \pm 0.004^{\mathrm{a}}$ & $0.192 \pm 0.010^{\mathrm{a}}$ \\
Fat & $3.47 \pm 0.21^{\mathrm{a}}$ & $1.77 \pm 0.06^{\mathrm{c}}$ & $2.75 \pm 0.11^{\mathrm{b}}$ & $3.49 \pm 0.11^{\mathrm{a}}$ & $3.68 \pm 0.09^{\mathrm{a}}$ \\
SNF & $8.86 \pm 0.23^{\mathrm{c}}$ & $8.83 \pm 0.16^{\mathrm{c}}$ & $8.88 \pm 0.17^{\mathrm{c}}$ & $9.79 \pm 0.33^{\mathrm{b}}$ & $11.05 \pm 0.15^{\mathrm{a}}$ \\
Protein & $3.26 \pm 0.11^{\mathrm{b}}$ & $3.31 \pm 0.07^{\mathrm{b}}$ & $3.34 \pm 0.16^{\mathrm{b}}$ & $3.85 \pm 0.15^{\mathrm{a}}$ & $4.36 \pm 0.18^{\mathrm{a}}$ \\
Lactose & $4.92 \pm 0.11^{\mathrm{c}}$ & $4.97 \pm 0.07^{\mathrm{c}}$ & $4.86 \pm 0.22^{\mathrm{c}}$ & $5.48 \pm 0.13^{\mathrm{b}}$ & $6.17 \pm 0.07^{\mathrm{a}}$ \\
\hline
\end{tabular}

${ }^{\text {a-c } M e a n s ~ w i t h i n ~ s a m e ~ r o w ~ w i t h ~ d i f f e r e n t ~ s u p e r s c r i p t s ~ a r e ~ s i g n i f i c a n t l y ~ d i f f e r e n t ~ b y ~ t h e ~ N e w m a n-K e u l s ~ t e s t ~}(P$ $<0.05)$.

${ }^{1}$ Target cheese milk fat and SNF percentages were as follows: Control $=3.5$ and $9.0 \% ; \mathrm{SM}_{\text {Half-fat }}=1.8$ and $9.0 \%$; $\mathrm{SM}_{3 / 4 \text {-fat }}=2.7$ and $9.0 \%$, respectively; $\mathrm{MPC}_{1.5}=3.5$ and $10.0 \% ; \mathrm{MPC}_{3.0}=3.5$ and $11.0 \%$.

\section{RESULTS AND DISCUSSION}

\section{Physicochemical Analysis of Cheese Milk and Cheeses}

As expected, the addition of skim milk significantly $(P<0.05)$ decreased the fat content of cheese milk, and the use of MPC resulted in a significant increase in acidity, SNF, protein, and lactose (Table 1). Composition of the Oaxaca cheeses is given in Table 2. The use of either skim milk or MPC caused a significant decrease in cheese fat and fat-in-dry matter (FDM) percentages $(P<0.05)$. However, the contents of cheese moisture, protein, and moisture in nonfat substance (MNFS) were not significantly affected by treatment. Contradictory data were found in literature with regard to the relationship between cheese fat and MNFS. Mistry

Table 2. Effect of using skim milk or milk protein concentrate (MPC) in standardizing cheese milk on chemical composition of cheeses and component recoveries to cheese and yields (mean values and standard deviations)

\begin{tabular}{|c|c|c|c|c|c|}
\hline \multirow[b]{2}{*}{ Item } & \multicolumn{4}{|c|}{ Treatment $^{1}$} & \multirow[b]{2}{*}{$\begin{array}{l}\mathrm{MPC}_{3.0} \\
(\mathrm{n}=3)\end{array}$} \\
\hline & $\begin{array}{l}\text { Control } \\
(\mathrm{n}=3)\end{array}$ & $\begin{array}{l}\mathrm{SM}_{\text {Half-fat }} \\
(\mathrm{n}=3)\end{array}$ & $\begin{array}{l}\mathrm{SM}_{3 / 4} \text {-fat } \\
(\mathrm{n}=3)\end{array}$ & $\begin{array}{l}\mathrm{MPC}_{1.5} \\
(\mathrm{n}=3)\end{array}$ & \\
\hline \multicolumn{6}{|l|}{ Cheese composition ${ }^{2}$} \\
\hline $\mathrm{pH}$ & $5.36 \pm 0.03$ & $5.39 \pm 0.11$ & $5.48 \pm 0.10$ & $5.27 \pm 0.14$ & $5.20 \pm 0.11$ \\
\hline Moisture (g/100 g) & $49.7 \pm 2.2$ & $54.0 \pm 5.5$ & $48.3 \pm 3.5$ & $51.6 \pm 2.6$ & $52.1 \pm 2.6$ \\
\hline Fat $(\mathrm{g} / 100 \mathrm{~g})$ & $24.8 \pm 0.9^{\mathrm{a}}$ & $14.8 \pm 1.2^{\mathrm{d}}$ & $23.0 \pm 1.1^{\mathrm{b}}$ & $22.5 \pm 1.0^{\mathrm{b}}$ & $19.6 \pm 0.4^{\mathrm{c}}$ \\
\hline Protein $(\mathrm{g} / 100 \mathrm{~g})$ & $21.8 \pm 1.0$ & $26.6 \pm 3.8$ & $23.5 \pm 2.3$ & $22.5 \pm 1.3$ & $23.5 \pm 1.4$ \\
\hline $\operatorname{Ash}(\mathrm{g} / 100 \mathrm{~g})$ & $3.1 \pm 0.3$ & $3.9 \pm 0.7$ & $3.7 \pm 0.2$ & $3.2 \pm 0.3$ & $3.1 \pm 0.2$ \\
\hline SNF (g/100 g) & $25.5 \pm 1.5$ & $31.2 \pm 4.6$ & $28.7 \pm 2.8$ & $26.2 \pm 1.7$ & $28.3 \pm 2.4$ \\
\hline FDM (g/100 g) & $49.3 \pm 0.9^{\mathrm{a}}$ & $32.4 \pm 2.2^{\mathrm{d}}$ & $44.6 \pm 2.1^{\mathrm{b}}$ & $45.8 \pm 0.6^{\mathrm{b}}$ & $40.9 \pm 1.8^{\mathrm{c}}$ \\
\hline $\operatorname{MNFS}(\mathrm{g} / 100 \mathrm{~g})$ & $66.1 \pm 2.3$ & $63.3 \pm 5.7$ & $63.7 \pm 3.9$ & $66.2 \pm 2.6$ & $64.8 \pm 3.6$ \\
\hline Lactose (g/100 g) & $0.17 \pm 0.13$ & $0.06 \pm 0.01$ & $0.06 \pm 0.04$ & $0.10 \pm 0.03$ & $0.08 \pm 0.03$ \\
\hline Galactose (g/100 g) & $0.18 \pm 0.05$ & $0.15 \pm 0.05$ & $0.20 \pm 0.05$ & $0.16 \pm 0.03$ & $0.27 \pm 0.10$ \\
\hline Lactic acid (g/100 g) & $1.27 \pm 0.07$ & $1.49 \pm 0.38$ & $1.32 \pm 0.12$ & $1.20 \pm 0.22$ & $1.67 \pm 0.20$ \\
\hline $\mathrm{NaCl}(\mathrm{mg} / 100 \mathrm{~g})$ & $1.09 \pm 0.10$ & $1.08 \pm 0.16$ & $0.87 \pm 0.05$ & $1.05 \pm 0.16$ & $0.97 \pm 0.20$ \\
\hline $\mathrm{Ca}(\mathrm{mg} / 100 \mathrm{~g})$ & $595 \pm 147$ & $982 \pm 228$ & $829 \pm 31$ & $729 \pm 195$ & $789 \pm 64$ \\
\hline $\mathrm{P}(\mathrm{mg} / 100 \mathrm{~g})$ & $363 \pm 69$ & $571 \pm 135$ & $473 \pm 13$ & $451 \pm 97$ & $471 \pm 31$ \\
\hline \multicolumn{6}{|c|}{$\begin{array}{l}\text { Component recoveries to cheese (\%) } \\
\text { and cheese yields }{ }^{3}\end{array}$} \\
\hline TS recovery & $49.1 \pm 1.1$ & $41.3 \pm 1.6$ & $46.5 \pm 1.8$ & $47.1 \pm 1.5$ & $46.8 \pm 1.6$ \\
\hline Fat recovery & $86.2 \pm 2.5$ & $80.1 \pm 2.8$ & $87.8 \pm 3.3$ & $84.4 \pm 1.1$ & $76.7 \pm 3.2$ \\
\hline SNF recovery & $34.7 \pm 1.8$ & $33.6 \pm 2.1$ & $33.7 \pm 1.5$ & $35.2 \pm 1.5$ & $36.8 \pm 1.5$ \\
\hline $\mathrm{Y}_{\mathrm{A}}$ & $12.06 \pm 0.38^{\mathrm{b}}$ & $9.57 \pm 0.72^{\mathrm{d}}$ & $10.48 \pm 0.70^{\mathrm{c}}$ & $13.15 \pm 0.25^{\mathrm{b}}$ & $14.43 \pm 0.91^{\mathrm{a}}$ \\
\hline $\mathrm{Y}_{\mathrm{DM}}$ & $6.06 \pm 0.12^{\mathrm{b}}$ & $4.38 \pm 0.21^{\mathrm{d}}$ & $5.40 \pm 0.10^{\mathrm{c}}$ & $6.53 \pm 0.33^{\mathrm{b}}$ & $6.89 \pm 0.18^{\mathrm{a}}$ \\
\hline $\mathrm{Y}_{\mathrm{FPAM}}$ & $12.18 \pm 0.22$ & $12.62 \pm 1.00$ & $11.72 \pm 1.06$ & $11.90 \pm 0.90$ & $12.21 \pm 0.72$ \\
\hline $\mathrm{Y}_{\mathrm{MA}}$ & $12.31 \pm 0.27^{\mathrm{b}}$ & $8.90 \pm 0.42^{\mathrm{d}}$ & $11.00 \pm 0.20^{\mathrm{c}}$ & $13.10 \pm 0.26^{\mathrm{b}}$ & $14.01 \pm 0.36^{\mathrm{a}}$ \\
\hline$Y_{\text {MA-FPAM }}$ & $12.45 \pm 0.79$ & $11.92 \pm 0.54$ & $12.28 \pm 0.75$ & $11.69 \pm 0.37$ & $11.85 \pm 0.56$ \\
\hline
\end{tabular}

${ }^{\mathrm{a}-\mathrm{d}}$ Means within same row with different superscripts are significantly different by the Newman-Keuls test $(P<0.05)$.

${ }^{1}$ Target cheese milk fat and SNF percentages were as follows: Control $=3.5$ and $9.0 \% ; \mathrm{SM}_{\text {Half-fat }}=1.8$ and $9.0 \% ; \mathrm{SM}_{3 / 4 \text {-fat }}=2.7$ and $9.0 \%$, respectively; $\mathrm{MPC}_{1.5}=3.5$ and $10.0 \% ; \mathrm{MPC}_{3.0}=3.5$ and $11.0 \%$.

${ }^{2} \mathrm{FDM}=$ fat in DM; MNFS $=$ moisture in nonfat substance.

${ }^{3} \mathrm{Y}_{\mathrm{A}}=$ actual yield; $\mathrm{Y}_{\mathrm{DM}}=\mathrm{DM}$ cheese yield; $\mathrm{Y}_{\mathrm{FPAM}}=$ actual yield adjusted to milk fat and protein reference levels; $\mathrm{Y}_{\mathrm{MA}}=$ moisture-adjusted yield; $\mathrm{Y}_{\mathrm{MA}-\mathrm{FPAM}}=$ moisture-adjusted yield adjusted to reference levels of fat and protein. 
Table 3. Selected predictive formulae for Oaxaca cheese moistureadjusted yield $\left(\mathrm{Y}_{\mathrm{MA}}\right)$ on the basis of cheese milk compositional characteristics (F: fat; P: protein, expressed as g/100 g)

\begin{tabular}{lcc}
\hline Formula $^{1}$ & $\mathrm{r}^{2}$ & $P$-value \\
\hline Control milk and skim milk-added batches & & \\
$\mathrm{Y}_{\mathrm{MA}}=1.917 \mathrm{~F}+5.624$ & 0.9076 & 0.0001 \\
$\mathrm{Y}_{\mathrm{MA}}=-1.302 \mathrm{SNF} / \mathrm{F}+15.410$ & 0.8852 & 0.0001 \\
$\mathrm{Y}_{\mathrm{MA}}=1.731 \mathrm{TS}-9.220$ & 0.8429 & 0.0005 \\
Control milk and MPC-added milk batches & & \\
$\mathrm{Y}_{\mathrm{MA}}=0.732 \mathrm{SNF}+5.787$ & 0.7714 & 0.0041 \\
$\mathrm{Y}_{\mathrm{MA}}=1.400 \mathrm{P}+7.706$ & 0.7080 & 0.0088 \\
$\mathrm{Y}_{\mathrm{MA}}=0.663 \mathrm{TS}+4.113$ & 0.7721 & 0.0041 \\
\hline
\end{tabular}

${ }^{1}$ Each formula was obtained from 9 pairs of points, 3 for each treatment considered. $\mathrm{MPC}=$ milk protein concentrate.

and Anderson (1993) found similar cheese MNFS contents in both low-fat and full-fat cheeses (Mozzarella, Cheddar, and Swiss). By contrast, Fenelon and Guinee (1999) found that cheese MNFS contents increased with increasing levels of cheese fat. Furthermore, Guinee et al. (2006) found MPC addition to decrease MNFS, and explained that when MPC was added, the curd was more prone to syneresis at cutting and stirring. Lactose, galactose, lactic acid, and $\mathrm{NaCl}$ contents of cheese were not influenced by the use of skim milk or MPC. Moreover, no significant differences were found between treatments in the levels calcium and phosphorous.

\section{Milk Component Recoveries to Cheese and Cheese Yields}

Milk component recoveries to cheese are shown in Table 2. Total solids and fat recoveries showed a (nonsignificant) tendency toward decrease when the cheese milk fat level was decreased to $1.7 \%$ ( $\mathrm{SM}_{\text {Half-fat }}$ batches) or the cheese milk protein was increased (MPC batches). In this way, a lower mean fat recovery was observed for the $\mathrm{MPC}_{3.0}$ batches, which were made from milk containing the highest level of protein $(4.4 \mathrm{~g} / 100 \mathrm{~g})$, compared with that of controls (no significant differences). The decreasing effect of cheese milk protein on fat recovery was observed by Fox et al. (2000) and Guinee et al. (2006). The former authors reported that cheese milk with a protein content comparable to that of $\mathrm{MPC}_{3.0}$ batches could result in a poor fat-retaining ability of the coagulum in the vat, and thereby high fat losses in cheese whey. Finally, compared with Oaxaca cheese controls, slightly lower SNF recoveries were found when using skim milk and slightly higher SNF recoveries were found when using MPC (differences not significant).

Actual, DM, and moisture-adjusted cheese yields significantly decreased $(P<0.05)$ with skim milk addition, but they increased with MPC addition (Table 2 ). However, normalized yields adjusted to milk fat and protein reference levels did not show significant differences between treatments.

Considering $\mathrm{SM}_{\text {Half-fat }}, \mathrm{SM}_{3 / 4 \text {-fat }}$, and control cheeses, the increase rate of actual yield with cheese milk fat $(1.34 \mathrm{~kg} / \mathrm{kg}, \mathrm{R}=0.88, P<0.05$; data not shown in tables) indicates that the contribution of cheese milk fat to the yield was more than its weight, which has been observed for other cheeses (Fenelon and Guinee, 1999; Fox et al., 2000). This has been attributed to a positive relationship between cheese milk fat and cheese MNFS contents, the latter representing the amount of moisture associated with the cheese protein. In our study, the correlation coefficient $(\mathrm{R})$ between those 2 characteristics was 0.60 .

Selected predictive equations for moisture-adjusted cheese yield derived from milk composition are shown in Table 3. Milk fat, SNF:fat ratio, and, to a lesser extent, TS contents were strong individual predictors of cheese yield. Coefficients of determination $\left(r^{2}\right)$ were between 0.8 and 0.9 .

Table 4. Effect of using skim milk or milk protein concentrate (MPC) in standardizing cheese milk on texture profiles of unmelted cheese, meltability, and free oil formation (mean values and standard deviations)

\begin{tabular}{|c|c|c|c|c|c|}
\hline \multirow[b]{2}{*}{ Item } & \multicolumn{5}{|c|}{ Treatment $^{1}$} \\
\hline & $\begin{array}{l}\text { Control } \\
(\mathrm{n}=3)\end{array}$ & $\begin{array}{l}\mathrm{SM}_{\text {Half-fat }} \\
(\mathrm{n}=3)\end{array}$ & $\begin{array}{l}\mathrm{SM}_{3 / 4 \text {-fat }} \\
(\mathrm{n}=3)\end{array}$ & $\begin{array}{l}\mathrm{MPC}_{1.5} \\
(\mathrm{n}=3)\end{array}$ & $\begin{array}{l}\mathrm{MPC}_{3.0} \\
(\mathrm{n}=3)\end{array}$ \\
\hline Hardness (N) & $22.0 \pm 4.9$ & $32.2 \pm 13.0$ & $30.8 \pm 9.3$ & $26.8 \pm 3.7$ & $31.4 \pm 6.3$ \\
\hline Adhesiveness (N s) & $1.36+0.43^{\mathrm{a}}$ & $0.35+0.21^{\mathrm{b}}$ & $1.42 \pm 0.77^{\mathrm{ab}}$ & $0.85+0.37^{\mathrm{ab}}$ & $1.08+0.33^{\mathrm{a}}$ \\
\hline Springiness $^{2}$ & $0.78 \pm 0.05^{\mathrm{b}}$ & $0.89 \pm 0.05^{\mathrm{a}}$ & $0.83 \pm 0.02^{\mathrm{ab}}$ & $0.83 \pm 0.01^{\mathrm{ab}}$ & $0.83 \pm 0.02^{\mathrm{ab}}$ \\
\hline Cohesiveness $^{2}$ & $0.65 \pm 0.02$ & $0.60 \pm 0.04$ & $0.62 \pm 0.05$ & $0.63 \pm 0.08$ & $0.61 \pm 0.07$ \\
\hline Meltability (\%) & $53.6 \pm 2.5^{\mathrm{a}}$ & $18.1 \pm 2.9^{\mathrm{c}}$ & $36.1 \pm 5.5^{\mathrm{b}}$ & $25.3 \pm 0.9^{c}$ & $24.3 \pm 4.0^{\mathrm{c}}$ \\
\hline Free oil (\%) & $8.6 \pm 1.7^{\mathrm{a}}$ & $1.2 \pm 0.1^{\mathrm{c}}$ & $4.0 \pm 1.3^{\mathrm{bc}}$ & $2.8 \pm 0.3^{\mathrm{bc}}$ & $4.4 \pm 1.7^{\mathrm{b}}$ \\
\hline
\end{tabular}


Table 5. Effect of the use of skim milk or milk protein concentrate (MPC) in standardizing cheese milk on sensory free oil and stretchability (mean values and standard deviations)

\begin{tabular}{|c|c|c|c|c|c|}
\hline \multirow[b]{2}{*}{ Item } & \multicolumn{5}{|c|}{ Treatment $^{1}$} \\
\hline & $\begin{array}{l}\text { Control } \\
(\mathrm{n}=3)\end{array}$ & $\begin{array}{l}\mathrm{SM}_{\text {Halfffat }} \\
(\mathrm{n}=3)\end{array}$ & $\begin{array}{l}\mathrm{SM}_{3 / 4-\mathrm{fat}} \\
(\mathrm{n}=3)\end{array}$ & $\begin{array}{l}\mathrm{MPC}_{1.5} \\
(\mathrm{n}=3)\end{array}$ & $\begin{array}{l}\mathrm{MPC}_{3.0} \\
(\mathrm{n}=3)\end{array}$ \\
\hline Free oil & $5.3 \pm 0.6$ & $3.3 \pm 0.6$ & $4.7 \pm 0.6$ & $4.3 \pm 0.6$ & $4.3 \pm 1.5$ \\
\hline Stretchability & $3.0 \pm 1.0^{\mathrm{b}}$ & $8.3 \pm 1.6^{\mathrm{a}}$ & $6.0 \pm 2.6^{\mathrm{ab}}$ & $5.0 \pm 1.0^{\mathrm{ab}}$ & $5.7 \pm 2.3^{\mathrm{ab}}$ \\
\hline
\end{tabular}

Taking only results of control and MPC-added batches into account, the addition of $1 \mathrm{~kg}$ of a commercial MPC (with a protein content of $40 \mathrm{~g} / 100 \mathrm{~g}$ ) resulted in an increase of approximately $0.8 \mathrm{~kg}$ of Oaxaca cheese. Thus, a double contribution of MPC protein to yield on a weight basis was observed $(\mathrm{R}=0.89$; data not shown in tables). An even higher rate $(\sim 3 \mathrm{~kg} / \mathrm{kg})$ was observed by Fox et al., 2000; Shakeel-Ur-Rehman et al., 2003; Guinee et al., 2006) for Cheddar cheese when milk for cheese manufacture was added with a MPC or an ultrafiltered milk retentate and standardized to a constant protein:fat ratio. Discrepancies could be explained by the fact that in those studies (in contrast to our experiment, where cheese milk fat content of control and MPC-added batches was fixed at a constant value), not only did the increase of cheese milk protein contribute to the increase in yield, but also to the concomitant increase in cheese milk fat. Finally, several selected predictive equations for moisture-adjusted cheese yield derived from milk chemical composition of control and skim milk batches are shown in Table 3 with TS and SNF, followed by protein concentrations being the strongest predictors, all of them showing $\mathrm{r}^{2}$ values between 0.7 and 0.8 .

\section{Cheese Functionality}

The effect of the use of skim milk or MPC on Oaxaca cheese functionality is shown in Tables 4 and 5 . In unmelted cheese, hardness tended to increase with the use of skim milk or MPC. Moreover, cheeses made using skim milk or MPC showed higher springiness than control cheeses (with significant differences being observed between control and $\mathrm{SM}_{\text {Half-fat }}$ batches; $P$ $<0.05)$. In addition, adhesiveness was the lowest for $\mathrm{SM}_{\text {Half-fat }}$ batches, showing significant differences with control and $\mathrm{MPC}_{3.0}(P<0.05)$. Cohesiveness was similar for all treatments.

The addition of skim milk or MPC to milk resulted in a decrease in cheese meltability and free oil (modified Gerber test) in the Oaxaca cheeses. Control batches also exhibited the highest scores for free oil, although differences were not significant. Stretchability increased with the use of skim milk and MPC. The $\mathrm{SM}_{\text {Half-fat }}$ cheeses showed the highest stretchability values, with significant differences being found between them and controls $(P<0.05)$.

In accordance with our results, an increase in hardness and an impairment of meltability due to a reduc-

Table 6. Linear correlation coefficients between selected compositional and functional characteristics of Oaxaca cheeses

\begin{tabular}{|c|c|c|c|c|c|c|c|}
\hline \multicolumn{8}{|c|}{$\begin{array}{l}\text { Control milk and skim } \\
\text { milk-added batches }\end{array}$} \\
\hline FDM & $-0.70^{\mathrm{a}}$ & $0.72^{\mathrm{a}}$ & $-0.79^{\mathrm{a}}$ & $0.97^{\mathrm{a}}$ & $0.87^{\mathrm{a}}$ & $0.83^{\mathrm{a}}$ & -0.83 \\
\hline MNFS & $-0.73^{\mathrm{a}}$ & 0.06 & -0.49 & 0.37 & 0.30 & 0.20 & -0.57 \\
\hline $\mathrm{Ca}_{\mathrm{SNF}}$ & 0.51 & -0.24 & $0.81^{\mathrm{a}}$ & -0.62 & $-0.68^{\mathrm{a}}$ & -0.44 & $0.67^{\mathrm{a}}$ \\
\hline \multicolumn{8}{|c|}{ Control milk and } \\
\hline MNFS & -0.57 & -0.28 & -0.17 & 0.18 & -0.31 & -0.17 & -0.32 \\
\hline $\mathrm{Ca}_{\mathrm{SNF}}$ & $0.73^{\mathrm{a}}$ & -0.02 & $0.80^{\mathrm{a}}$ & -0.60 & -0.53 & -0.21 & 0.60 \\
\hline
\end{tabular}

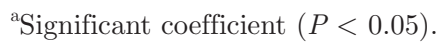

${ }^{1} \mathrm{FDM}=$ fat in DM; MNFS $=$ moisture in nonfat substance; CaasF $=$ calcium content in cheese SNF; MPC = milk protein concentrate.

${ }^{2}$ Modified Gerber test.

${ }^{3}$ Sensory measurement. 


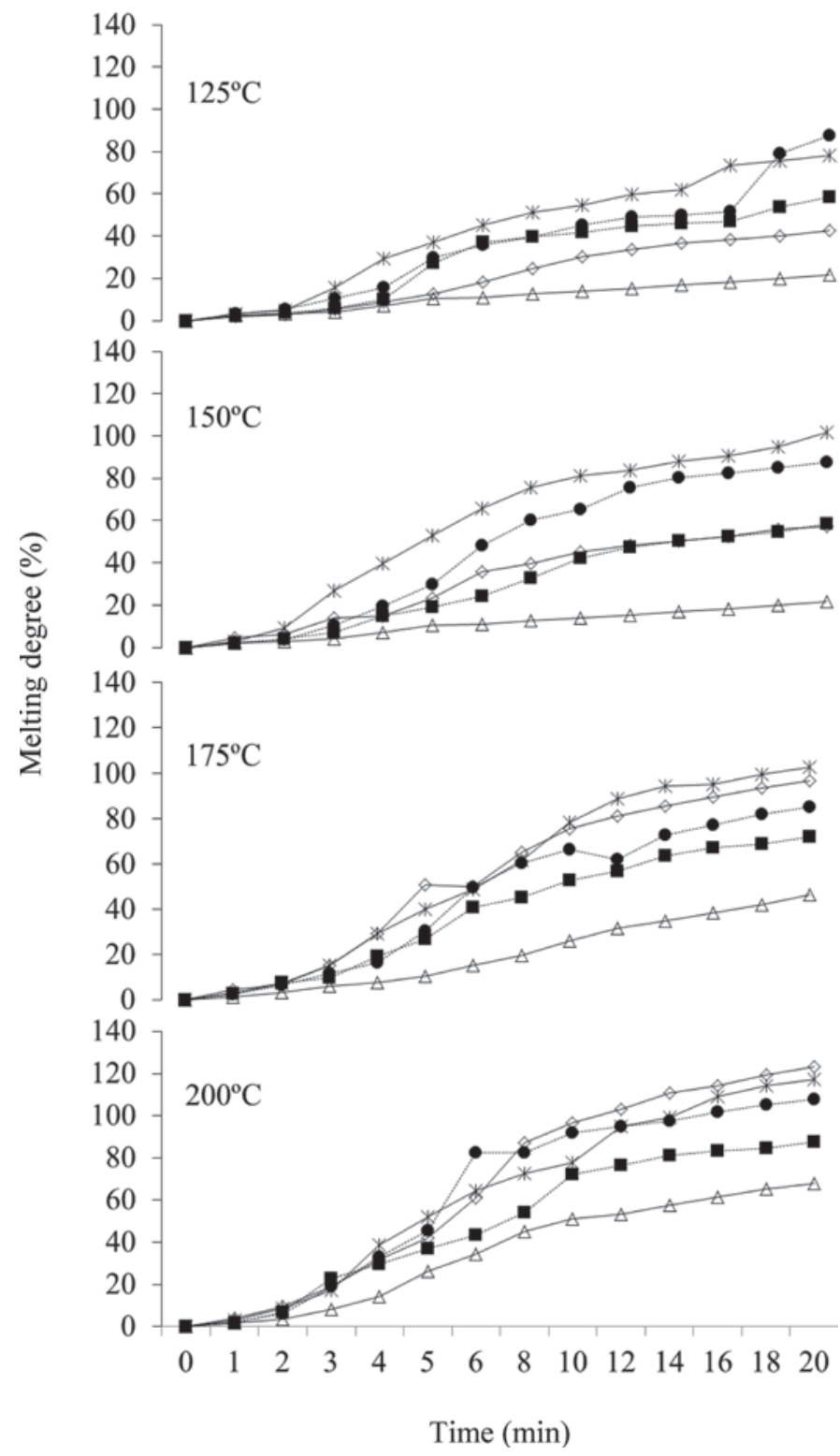

Figure 1. Meltability of Oaxaca cheese during baking (up to 20 $\min )$ at different temperatures (Control $=* ; \mathrm{SM}_{\text {Half-fat }}=\diamond, \mathrm{SM}_{3 / 4 \text {-fat }}$ $\left.=\Delta ; \mathrm{MPC}_{1.5}=\mathbf{\square} ; \mathrm{MPC}_{3.0}=\bullet\right) . \mathrm{MPC}=$ milk protein concentrate Target cheese milk fat and SNF percentages were as follows: Control $=3.5$ and $9.0 \% ; \mathrm{SM}_{\text {Halffat }}=1.8$ and $9.0 \% ; \mathrm{SM}_{3 / 4 \text {-fat }}=2.7$ and $9.0 \%$, respectively; $\mathrm{MPC}_{1.5}=3.5$ and $10.0 \% ; \mathrm{MPC}_{3.0}=3.5$ and $11.0 \%$.

tion in fat content or an increase in protein concentration of cheese milk, were reported for low-moisture, part-skim Mozzarella (Rudan et al., 1999) and Cheddar cheeses (Oommen et al., 2000). As suggested by the latter authors, the higher hardness observed in cheeses from milk with increased protein contents could be attributable to a stronger protein network and a lower ability of fat and protein phases to move in relation to each other.
In this study, it was observed that cheese FDM and MNFS correlated negatively with hardness and that calcium in SNF correlated positively with hardness and springiness (Table 6). Furthermore, meltability and free oil formation (the latter chiefly when considering control and skim milk-added cheeses) correlated positively with cheese FDM and negatively with calcium in cheese SNF; the opposite was found for stretchability.

The effect of the cheese milk composition on the Oaxaca cheese melt characteristics (meltability, stretchability, and free oil) could be explained in part by the resulting differences in cheese composition (i.e., FDM, calcium in cheese SNF; $P<0.05$, data not shown). In agreement with this, cheese fat, together with moisture content and the structure of the paracasein gel network, have been shown to be main factors responsible for the functional characteristics of low-moisture Mozzarella (Kindstedt, 1993; McMahon and Oberg, 1998).

Meltability of Oaxaca cheese during baking at different temperatures $\left(125,150,175\right.$, and $200^{\circ} \mathrm{C}$ ) increased with baking time (Figure 1). Nonetheless, the higher extension rate was observed between min 2 and 6 , which agrees with the results found by Wang and Sun (2002) for Mozzarella cheese. At baking temperatures of 125 and $150^{\circ} \mathrm{C}$, the use of skim milk or MPC resulted in cheeses with lower melting rates compared with control cheeses. However, above $150^{\circ} \mathrm{C}$, the melting rate of $\mathrm{SM}_{3 / 4 \text {-fat }}$ and $\mathrm{MPC}_{1.5}$ cheeses equaled that of control cheeses, with the $\mathrm{SM}_{\text {Half-fat }}$ cheeses showing the lowest melting rates at all temperatures.

Color characteristics of unmelted and baked cheeses (after the 20-min baking period) are shown in Table 7 . Neither the addition of skim milk nor MPC affected Oaxaca cheese color (unmelted). On the contrary, in unmelted cheese, Rudan et al. (1999) found that a reduction in Mozzarella-cheese fat content implied a significant decrease in whiteness. With regard to browning on baking, which has been associated with the presence of substrate molecules for the amino-carbonyl reaction (Imm et al., 2003), cheese milk composition did not exert any significant effect on Oaxaca cheese browning. However, browning increased with higher baking temperatures.

\section{CONCLUSIONS}

The additions of either skim milk or MPC to cheese milk, in the amounts used in the present study, are 2 feasible ways to obtain reduced-fat Oaxaca cheeses. The use of MPC had an advantage over skim milk in that it resulted in higher actual cheese yields. However, solids recoveries to cheese and normalized yields adjusted to milk fat at protein reference levels were scarcely affected in reduced-fat Oaxaca cheeses with respect to controls. 
Table 7. Effect of the use of skim milk or milk protein concentrate (MPC) in standardizing cheese milk on color characteristics of unmelted and melted Oaxaca cheese samples after 20-min baking at different temperatures $\left(125,150,175\right.$, and $200^{\circ} \mathrm{C}$; mean values and standard deviations)

\begin{tabular}{|c|c|c|c|c|c|}
\hline \multirow[b]{2}{*}{ Item } & \multicolumn{5}{|c|}{ Treatment $^{1}$} \\
\hline & $\begin{array}{l}\text { Control } \\
(\mathrm{n}=3)\end{array}$ & $\begin{array}{l}\mathrm{SM}_{\text {Half-fat }} \\
(\mathrm{n}=3)\end{array}$ & $\begin{array}{l}\mathrm{SM}_{3 / 4-\mathrm{fat}} \\
(\mathrm{n}=3)\end{array}$ & $\begin{array}{l}\mathrm{MPC}_{1.5} \\
(\mathrm{n}=3)\end{array}$ & $\begin{array}{l}\mathrm{MPC}_{3.0} \\
(\mathrm{n}=3)\end{array}$ \\
\hline \multicolumn{6}{|c|}{$L^{*}$ (white-black component) } \\
\hline Initial & $83.0 \pm 3.3^{\mathrm{a}}$ & $81.4 \pm 2.0^{\mathrm{a}}$ & $83.2 \pm 0.7^{\mathrm{a}}$ & $79.5 \pm 1.4^{\mathrm{a}}$ & $81.3 \pm 3.3^{\mathrm{a}}$ \\
\hline $125^{\circ} \mathrm{C}$ & $66.9 \pm 2.6^{\mathrm{b}}$ & $62.2 \pm 3.6^{2}$ & $63.4 \pm 3.0^{\mathrm{b}}$ & $63.9 \pm 3.8^{\mathrm{b}}$ & $65.0 \pm 4.5^{\mathrm{b}}$ \\
\hline $150^{\circ} \mathrm{C}$ & $62.0 \pm 2.2^{\mathrm{bc}}$ & $58.4 \pm 3.5^{\mathrm{bc}}$ & $60.6 \pm 4.6^{\mathrm{b}}$ & $61.2 \pm 4.7^{\mathrm{b}}$ & $62.0 \pm 6.6^{\mathrm{bc}}$ \\
\hline $175^{\circ} \mathrm{C}$ & $56.6 \pm 6.9^{\mathrm{bc}}$ & $52.3 \pm 5.3^{\mathrm{bc}}$ & $52.5 \pm 4.1^{\mathrm{b}}$ & $57.4 \pm 6.2^{\mathrm{bc}}$ & $56.8 \pm 3.5^{\mathrm{bc}}$ \\
\hline $200^{\circ} \mathrm{C}$ & $53.6 \pm 3.7^{\mathrm{c}}$ & $50.3 \pm 3.3^{\mathrm{c}}$ & $56.4 \pm 4.5^{\mathrm{b}}$ & $58.9 \pm 4.0^{\mathrm{c}}$ & $51.4 \pm 1.1^{\mathrm{c}}$ \\
\hline \multicolumn{6}{|c|}{$a^{*}$ (red-green component) } \\
\hline Initial & $-0.8 \pm 0.6^{\mathrm{b}}$ & $-1.3 \pm 0.3^{\mathrm{c}}$ & $-0.8 \pm 0.4^{\mathrm{c}}$ & $-1.2 \pm 0.4^{\mathrm{c}}$ & $-1.2 \pm 0.1^{\mathrm{b}}$ \\
\hline $125^{\circ} \mathrm{C}$ & $0.1 \pm 0.9^{\mathrm{b}}$ & $-0.4 \pm 0.9^{\mathrm{c}}$ & $0.6 \pm 1.1^{\mathrm{bc}}$ & $0.5 \pm 2.1^{\mathrm{bc}}$ & $-1.0 \pm 0.6^{\mathrm{b}}$ \\
\hline $150^{\circ} \mathrm{C}$ & $1.6 \pm 0.2^{\mathrm{b}}$ & $2.6 \pm 0.4^{\mathrm{c}}$ & $1.4 \pm 0.6^{\mathrm{ab}}$ & $1.4 \pm 1.6^{\mathrm{bc}}$ & $0.4 \pm 1.6^{\mathrm{b}}$ \\
\hline $175^{\circ} \mathrm{C}$ & $7.5 \pm 4.6^{\mathrm{a}}$ & $6.8 \pm 1.4^{\mathrm{ab}}$ & $6.7 \pm 1.5^{\mathrm{a}}$ & $6.1 \pm 4.7^{\mathrm{b}}$ & $4.6 \pm 2.0^{\mathrm{ab}}$ \\
\hline $200^{\circ} \mathrm{C}$ & $9.3 \pm 2.4^{\mathrm{a}}$ & $11.4 \pm 1.9^{\mathrm{a}}$ & $6.0 \pm 4.0^{\mathrm{a}}$ & $9.5 \pm 5.3^{\mathrm{a}}$ & $8.7 \pm 3.0^{\mathrm{a}}$ \\
\hline \multicolumn{6}{|c|}{$b^{*}$ (yellow-blue component) } \\
\hline Initial & $17.5 \pm 1.5^{\mathrm{d}}$ & $15.7 \pm 1.0^{\mathrm{c}}$ & $17.2 \pm 0.6^{\mathrm{c}}$ & $16.8 \pm 0.9^{\mathrm{b}}$ & $16.8 \pm 0.4^{\mathrm{c}}$ \\
\hline $125^{\circ} \mathrm{C}$ & $20.4 \pm 1.0^{\mathrm{cd}}$ & $20.8 \pm 1.6^{\mathrm{bc}}$ & $21.2 \pm 0.2^{\mathrm{bc}}$ & $21.2 \pm 3.9^{\mathrm{ab}}$ & $18.8 \pm 1.3^{\mathrm{bc}}$ \\
\hline $150^{\circ} \mathrm{C}$ & $22.9 \pm 0.1^{\mathrm{b}}$ & $24.6 \pm 2.3^{\mathrm{b}}$ & $21.9 \pm 1.2^{\mathrm{abc}}$ & $23.2 \pm 2.2^{\mathrm{ab}}$ & $22.2 \pm 1.6^{\mathrm{abc}}$ \\
\hline $175^{\circ} \mathrm{C}$ & $28.4 \pm 3.8^{\mathrm{ab}}$ & $26.7 \pm 2.7^{\mathrm{b}}$ & $27.5 \pm 3.3^{\mathrm{ab}}$ & $27.4 \pm 5.0^{\mathrm{a}}$ & $25.5 \pm 3.2^{\mathrm{ab}}$ \\
\hline $200^{\circ} \mathrm{C}$ & $30.3 \pm 3.6^{\mathrm{a}}$ & $30.0 \pm 1.5^{\mathrm{a}}$ & $28.1 \pm 0.9^{\mathrm{a}}$ & $27.8 \pm 3.0^{\mathrm{a}}$ & $29.1 \pm 3.9^{\mathrm{a}}$ \\
\hline
\end{tabular}

${ }^{\mathrm{a}-\mathrm{d}}$ Means within column with different superscript are significantly different by the Newman-Keuls test $(P<$ 0.05). No statistical differences were detected between cheese batches.

${ }^{1}$ Target cheese milk fat and SNF percentages were as follows: Control $=3.5$ and $9.0 \% ; \mathrm{SM}_{\text {Half-fat }}=1.8$ and $9.0 \%$; $\mathrm{SM}_{3 / 4 \text {-fat }}=2.7$ and $9.0 \%$, respectively; $\mathrm{MPC}_{1.5}=3.5$ and $10.0 \% ; \mathrm{MPC}_{3.0}=3.5$ and $11.0 \%$.

With regard to cheese functionality, stretchability and free oil properties were more favorable in reduced-fat Oaxaca cheeses that in control cheeses; on the other hand, meltability was lower. Additional studies are needed to investigate to what extent consumers appreciate these quality characteristics. Moreover, results of the 20-min baking test provided evidence of an interaction between cheese milk composition (i.e., cheese fat) and baking temperature for cheese meltability.

\section{ACKNOWLEDGMENTS}

This work was financially supported by the Mexican Government PROMEP-SEP program (2005-2008).

\section{REFERENCES}

Aguilar-Uscanga, B. R., R. Montero-Lagunes, J. De la Cruz, J. R. Solís-Pacheco, and H. S. García. 2006. Using fermented cheese whey to reduce acidification time of Oaxaca cheese. Agrociencia 40:569-575.

AOAC. 1999. Official Methods of Analysis. Vol. II. 16th ed. Association of Official Analytical Chemists, Gaithersburg, MD.

Childs, J. L., and M. Drake. 2009. Consumer perception of fat reduction in cheese. J. Sens. Stud. 24:902-921.

Fenelon, M. A., and T. P. Guinee. 1999. The effect of milk fat on cheddar cheese yield and its prediction, using modifications of the Van Slyke cheese yield formula. J. Dairy Sci. 82:2287-2299.

Fox, P. F., T. P. Guinee, T. M. Cogan, and P. L. H. McSweeney. 2000. Fundamentals of Cheese Science. Aspen Publishers, Gaithersburg, $\mathrm{MD}$

González de Llano, D., A. Rodríguez, and P. Cuesta. 1996. Effect of lactic starter cultures on the organic acid composition of milk and cheese during ripening-analysis by HPLC. J. Appl. Bacteriol. 80:570-576.

Govindasamy-Lucey, S., T. Lin, J. J. Jaeggi, C. J. Martinelli, M. E. Johnson, and J. A. Lucey. 2007. Effect of type of concentrated sweet cream buttermilk on the manufacture, yield, and functionality of pizza cheese. J. Dairy Sci. 90:2675-2688.

Guinee, T. P., B. T. O'Kennedy, and P. M. Kelly. 2006. Effect of milk protein standardization using different methods on the composition and yields of Cheddar cheese. J. Dairy Sci. 89:468-482.

Imm, J. Y., E. J. Oh, K. S. Han, S. Oh, Y. W. Park, and S. H. Kim. 2003. Functionality and physico-chemical characteristics of bovine and caprine Mozzarella cheeses during refrigerated storage. J. Dairy Sci. 86:2790-2798.

ISO. 1993. International Standard 8586. Sensory Analysis Methodology - General Guidance for the Selection, Training and Monitoring of Assessors. Part 1: Selected Assessors. International Organisation for Standardisation, Geneva, Switzerland.

ISO. 2008. International Standard 8589. Sensory Analysis-General Guidance for the Design of Text Rooms. International Organisation for Standardisation, Geneva, Switzerland.

Kameswaran, S., and D. E. Smith. 1999. Rennet clotting times of skim milk based rennet gels supplemented with an ultrafiltered milk protein concentrate. Milchwissenschaft 54:546-550.

Kindstedt, P. S. 1993. Effect of manufacturing factors, composition and proteolysis on the functional characteristics of Mozzarella cheese. Crit. Rev. Food Sci. Nutr. 33:167-187.

Kindstedt, P. S., and P. F. Fox. 1991. Modified Gerber test for free oil in melted Mozzarella cheese. J. Food Sci. 56:1115-1116.

McMahon. D. J., and C. J. Oberg. 1998. Influence of fat, moisture and salt on function properties of mozzarella cheese. Aust. J. Dairy Technol. 53:98-101.

Mistry, V. V. 2001. Low fat cheese technology. Int. Dairy J. 11:413422.

Mistry, V. V., and D. L. Anderson. 1993. Composition and microstructure of commercial full-fat and low-fat cheeses. Food Structure $12: 259-266$

Oommen, B. S., V. V. Mistry, and M. G. Nair. 2000. Effect of homogenization of cream on composition, yield, and functionality of 
Cheddar cheese made from milk supplemented with ultrafiltered milk. Lait 80:77-91.

Osorio, M. T., J. M. Zumalacárregui, B. Bermejo, A. Lozano, A. C. Figueira, and J. Mateo. 2007. Effect of ewe's milk versus milkreplacer rearing on mineral composition of suckling lamb meat and liver. Small Rumin. Res. 68:296-302.

Richoux, R., G. Roset, M. H. Famelart, and J. R. Kerjean. 2001. Diversité de quelques propriétés fonctionnelles á chaud de I'Emmental français. Lait 81:547-559.

Rodríguez, J. 1998. Recent advances in the development of low-fat cheese. Trends Food Sci. Technol. 9:249-254.

Rudan, M. A., D. M. Barbano, J. J. Yun, and P. S. Kindstedt. 1999. Effect of fat reduction on chemical composition, proteolysis, functionality, and yield of Mozzarella cheese. J. Dairy Sci. 82:661672
Shakeel-Ur-Rehman, N. Y. Farkye, T. Considine, A. Schaffner, and M. A. Drake. 2003. Effects of standardization of whole milk with dry milk protein concentrate on the yield and ripening of reduced fat Cheddar cheese. J. Dairy Sci. 86:1608-1615.

USDA. 1980. USDA Specifications for Mozzarella Cheeses. Agricultural Marketing Service, USDA, Washington, DC.

Van Vliet, T. 1991. Terminology to be used in cheese rheology. Pages 5-15 in Rheological and Fracture Properties of Cheese. IDF Bull. No. 268, International Dairy Federation, Brussels, Belgium.

Wang, H. H., and D. W. Sun. 2002. Melting characteristics of cheese: Analysis of effects of cooking conditions using computer vision technology. J. Food Eng. 51:305-310. 